\title{
Thermal analysis of solvatomorphic decakis (dimethylammonium) dihydrogendodecatungstate hydrates
}

\author{
László Trif ${ }^{1}$. Fernanda P. Franguelli ${ }^{1,2}$. György Lendvay ${ }^{1} \cdot$ Eszter Majzik $^{1} \cdot$ Kende Béres $^{1} \cdot$ Laura Bereczki $^{1}$. \\ Imre M. Szilágyi ${ }^{2} \cdot$ Rajandra P. Pawar $^{3}$. László Kótai ${ }^{1,4}$
}

Received: 3 September 2020 / Accepted: 14 December 2020 / Published online: 5 February 2021

(c) The Author(s) 2021

\begin{abstract}
This study aims to describe the thermal decomposition of two solvatomorphs of decakis(dimethylammonium) dihydrogendodecatungstate $\left(\left(\mathrm{Me}_{2} \mathrm{NH}_{2}\right)_{10} \mathrm{H}_{2} \mathrm{~W}_{12} \mathrm{O}_{42} \cdot 10 \mathrm{H}_{2} \mathrm{O}\right.$ and $\left.11 \mathrm{H}_{2} \mathrm{O}\right)$ under inert and oxidizing atmospheres. Thermal studies have been done by TG-MS, TG-DSC-MS, XRD and IR methods in both synthetic air and helium atmospheres. The general characteristics of thermal decomposition are similar for both solvatomorphs. Minor differences could be observed in the resolution and shifting of the decomposition peak temperatures depending on the heating rate or atmosphere used. The first step of decomposition is endothermic in both atmospheres and involves 2 and 5 water molecule elimination with $\sim 150$ and $\sim 120{ }^{\circ} \mathrm{C}$ peak temperatures for the decahydrate and undecahydrate, respectively. The elimination of further water and dimethylamine was observed with increasing the temperature, as well as the disruption of the lattice of compounds. Until $300{ }^{\circ} \mathrm{C}$, these processes are endothermic in both atmospheres, and the further decomposition processes at higher temperatures are left endothermic in helium, but become exothermic in synthetic air atmosphere. In helium atmosphere, above $350{ }^{\circ} \mathrm{C}$, a solid-phase quasi-intramolecular redox reaction takes place when the dimethylamine degradation products react with the $\mathrm{W}=\mathrm{O}$ bonds with formation of oxidative coupling products of the organic fragments and reduced tungsten oxide with $\mathrm{WO}_{\sim 2.93}$ composition. In synthetic air, above $350{ }^{\circ} \mathrm{C}$, burning of organic fragments takes place, there are no oxidative coupling products and reduced tungsten oxide formation, and the end product of decomposition is monoclinic $\mathrm{WO}_{3}$.
\end{abstract}

Keywords Thermal studies · Quasi-intramolecular redox reaction · Dehydration · DSC $\cdot$ TG-MS $\cdot$ Paratungstate B

\section{Introduction}

Polyoxometalate compounds (POMs), especially polytungstates (POTs), represent an extensively studied area of material chemistry. There is an emerging interest about

Fernanda P. Franguelli

fernandapaivafranguelli@edu.bme.hu

László Kótai

kotai.laszlo@ttk.hu

1 Institute of Materials and Environmental Chemistry, Research Centre for Natural Sciences, ELKH, Magyar Tudósok krt 2, Budapest, Hungary

2 Department of Inorganic and Analytical Chemistry, Budapest University of Technology and Economics, Budapest 1111, Hungary

3 Department of Chemistry, Deogiri College, Station Road, Aurangabad 431005, India

4 Deuton-X Ltd, Selmeci u. 89, Érd 2030, Hungary thermal decomposition of POMs having ammonium cations for the synthesis of metal oxides to be used as catalysts [1-4]. Alkylamino polytungstates [4-7], containing reducing alkylammonium cations with oxidizing polytungstate anions, are particularly interesting because of the possibility of self-oxidation, and because the cation may be volatilized. Recently, some polymorphic and solvatomorphic dimethylammonium dihydrogendodecatungstates have been synthesized $[4,8,9]$. The structure of these modifications is remarkably different, their water content is also different, and the cation-anion interactions [8] involve numerous biand multifurcated hydrogen bonds. As a result, their thermal properties are rather interesting, and their decomposition involves concomitant evolution of amine and water. The possibility of redox reactions between the oxometalate anionic cage and reducing $\mathrm{N}-\mathrm{H}$ functional group of the cation offers further curiosities in their thermal behavior, which has not been established yet. 
In the present work, continuing our work on dimethylammonium dihydrogendodecatungstate solvatomorphs, [8, 9] the results of combined thermal studies (TG, TG-MS, DSC) on $\left(\mathrm{Me}_{2} \mathrm{NH}_{2}\right)_{10}\left[\mathrm{H}_{2} \mathrm{~W}_{12} \mathrm{O}_{42}\right] \cdot 10 \mathrm{H}_{2} \mathrm{O}$ (compound 1a) and $\left(\mathrm{Me}_{2} \mathrm{NH}_{2}\right)_{10}\left[\mathrm{H}_{2} \mathrm{~W}_{12} \mathrm{O}_{42}\right] \cdot 11 \mathrm{H}_{2} \mathrm{O}$ (compound 1b) are presented.

\section{Experimental}

Chemical-grade ammonium paratungstate, $40 \%$ aq. dimethylamine solution and other analytical reagents were obtained from Deuton-X Ltd., Hungary.

$\mathrm{WO}_{3}$ as precursor was prepared by the method of Fait et al. [10] with heating of ammonium paratungstate $\left(\left(\mathrm{NH}_{4}\right)_{10} \mathrm{H}_{2} \mathrm{~W}_{12} \mathrm{O}_{42}\right)$ at $600{ }^{\circ} \mathrm{C}$ for $10 \mathrm{~min}$. The freshly prepared monoclinic $\mathrm{WO}_{3}$ was reacted with $40 \%$ aq. dimethylamine solution at $50{ }^{\circ} \mathrm{C}$ for $2 \mathrm{~h}$ and the compound 1a was precipitated out with addition of ethanol. The white powdery material was recrystallized from water to obtain compound 1b. Both compounds were identified by their IR and XRD traces [8, 9].

X-ray powder diffraction measurements were performed on a Philips PW-1050 system with a Bragg-Brentano parafocusing goniometer. The apparatus was equipped with a copper tube ( $40 \mathrm{kV}, 35 \mathrm{~mA}$ tube current), a secondary beam graphite monochromator and a proportional counter. Scans were recorded in step mode. The diffraction patterns were evaluated by full profile fitting techniques.

FTIR measurements were recorded on a Jasco FT/ IR-4600 system at room temperature. The FTIR instrument was equipped with a Jasco ATR Pro One single reflection diamond ATR accessory (incident angle $45^{\circ}$ ), furthermore with a DLATGS detector $\left(4000-400 \mathrm{~cm}^{-1}\right.$ region, resolution of $4 \mathrm{~cm}^{-1}$ and co- addition of 64 individual spectra). An ATR correction (Jasco Spectra Manager version 2, Spectra analysis module version 2.15.11) was performed on the raw spectra.

Simultaneous thermogravimetric, differential scanning calorimetric and mass spectrometric evolved gas analysis (TG-DSC-MS) measurements under inert conditions were performed on a Setaram LabsysEvo thermal analyzer, in high-purity helium (6.0) atmosphere, with a flow rate of $90 \mathrm{~mL} \mathrm{~min}{ }^{-1}$. The measurements were recorded in the $25-700{ }^{\circ} \mathrm{C}$ temperature range, with a heating rate of $20{ }^{\circ} \mathrm{C}$ $\min ^{-1}$, and samples were weighed into $100 \mu \mathrm{L}$ alumina crucibles. The obtained data were baseline corrected and further evaluated by the thermoanalyzer's processing software (Calisto Processing, ver. 2.01). Simultaneously with the TG-DSC measurement, the analysis of the evolved gases/ decomposition products was carried out on a Pfeiffer Vacuum OmniStar ${ }^{\mathrm{TM}}$ quadrupole mass spectrometer coupled to the above-described TGA. The gas splitters and transfer lines to the spectrometer were thermostated to $220^{\circ} \mathrm{C}$. The measurements were taken in SEM Bargraph Cycles acquisition mode, in which the total ion current (TIC), the analog bar graph spectra (for structure determination), and the separate ion current of each scanned individual mass (96 masses) were recorded. The scanned mass interval was 5-100 amu, with a scan speed of $20 \mathrm{~ms} \mathrm{amu}^{-1}$, and the spectrometer was operated in electron impact mode. The measurements under synthetic air atmosphere were done with the same conditions and instruments.

\section{Results and discussion}

The thermal decomposition of compounds $\mathbf{1 a}$ and $\mathbf{1 b}$ were studied in inert atmosphere (helium) and in synthetic air. The decomposition temperatures, mass loss and the evolved gas fragments together with TG-DSC-MS characteristics are given in both atmospheres for compounds $\mathbf{1 a}$ and $\mathbf{1 b}$ in Table 1 and 2 .

First, we summarize the general features of the heating curves and the mass losses of the two compounds in the two atmospheres. In the graphical representation shown in Figs. 1 and 2 and ESI Figs. 1-5, one can see that the TG curves measured for compound $\mathbf{1 a}$ in inert and oxidizing atmospheres are almost identical until about $300{ }^{\circ} \mathrm{C}$. The mass loss in the oxygen-containing atmosphere becomes first (starting at about $330{ }^{\circ} \mathrm{C}$ ) faster, but above about $380{ }^{\circ} \mathrm{C}$, which is significant slower than in helium. The same holds for compound $\mathbf{1 b}$, except that for the latter the steps are more expressed.

The multiple steps indicate that the leaving constituents (water and dimethylamine) evolve in several steps from both compounds, and their binding energies are different in the crystal lattices of $\mathbf{1 a}$ and $\mathbf{1 b}$. The number of steps and the mass losses associated with each step are different for the two compounds. All reaction steps in inert atmosphere are strongly endothermic (Figs. 3, 4 and Table 1), while in synthetic air, the decomposition processes were found to be endothermic below and strongly exothermic above $300{ }^{\circ} \mathrm{C}$ (Figs. 3, 4 and Table 2).

Since in our compounds there are strongly reducing cations and oxidizing anions, one can expect a thermally induced redox reaction between them. The occurrence of such kind of redox reactions within one compound having oxidizing and reducing components is well documented in the literature [11-17]. Since in inert atmosphere the decomposition steps are endothermic, one can conclude that the energy required for elimination of water and dimethylamine as well as the disruption of the lattice exceeds the exothermicity of the redox interaction. The behavior of compounds $\mathbf{1 a}$ and $\mathbf{1 b}$ is similar, in spite of the important difference between their crystal structures [8]. 
Table 1 Thermal decomposition characteristics of compounds $\mathbf{1 a}$ and $\mathbf{1 b}$ in inert atmosphere

\begin{tabular}{|c|c|c|c|c|c|c|}
\hline Step & $\begin{array}{l}\text { Tem- } \\
\text { perature } \\
\text { range } /{ }^{\circ} \mathrm{C}\end{array}$ & $\Delta m / \%$ & $\begin{array}{l}\text { DTG peak } \\
\text { temperature } /{ }^{\circ} \mathrm{C}\end{array}$ & $\begin{array}{l}\text { DSC peak } \\
\text { temperature } /{ }^{\circ} \mathrm{C}\end{array}$ & $\Delta H / \mathrm{kJ} \mathrm{mol}^{-1}$ & Main fragments $/ \mathrm{m} / \mathrm{z}$ values \\
\hline \multicolumn{7}{|l|}{$1 \mathbf{a}$} \\
\hline 1 & $60-155$ & -1.04 & 140.5 & 140.7 & 89.672 & $18,17,16\left(\mathrm{H}_{2} \mathrm{O}\right)$ \\
\hline 2 & $155-269$ & -8.73 & 200.6 & 199.4 & 551.857 & $18,17,16\left(\mathrm{H}_{2} \mathrm{O}\right) ; 45,44,43,42\left(\mathrm{Me}_{2} \mathrm{NH}\right)$ \\
\hline 3 & 269-399 & -6.69 & 361.1 & 346 & 648.645 & $\begin{array}{l}18,17,16\left(\mathrm{H}_{2} \mathrm{O}\right) ; 45,44,43,42\left(\mathrm{Me}_{2} \mathrm{NH}\right) ; 60,59,58 \text { (coupling } \\
\text { products) }\end{array}$ \\
\hline 4 & $399-487$ & -1.10 & 417.6 & 406 & 134.248 & $\begin{array}{l}18,17,16\left(\mathrm{H}_{2} \mathrm{O}\right) ; 45,44,43,42\left(\mathrm{Me}_{2} \mathrm{NH}, \text { small }\right) ; 30,28(\mathrm{NO}, \mathrm{CO} / \\
\mathrm{N}_{2} \text { as oxidation products, small); } 60,59,58 \text { (coupling products, } \\
\text { small) }\end{array}$ \\
\hline 5 & $487-703$ & -0.49 & & & & $18,17,16\left(\mathrm{H}_{2} \mathrm{O}\right)$ \\
\hline \multicolumn{7}{|l|}{ 1b } \\
\hline 1 & $35-143$ & -4.33 & $\begin{array}{l}117.4 \\
131.3\end{array}$ & 117.4 & 210.534 & $18,17,16\left(\mathrm{H}_{2} \mathrm{O}\right)$ \\
\hline 2 & $143-176$ & -1.04 & 154.2 & 157.9 & 36.904 & $\begin{array}{l}18,17,\left(\mathrm{H}_{2} \mathrm{O}\right) ; 45,44,43,42\left(\mathrm{Me}_{2} \mathrm{NH}, \text { small }\right) ; 30,28\left(\mathrm{NO}, \mathrm{CO} / \mathrm{N}_{2} \text {, }\right. \\
\text { oxidation product, small); }\end{array}$ \\
\hline $3 a$ & $176-283$ & -6.99 & 234.7 & 234.5 & 375.022 & $18,17,16\left(\mathrm{H}_{2} \mathrm{O}\right)$ \\
\hline 4 & $283-409$ & -6.07 & 365.4 & 365.4 & 330.562 & $45,44,43,42\left(\mathrm{Me}_{2} \mathrm{NH},\right)$ \\
\hline 5 & $409-490$ & -1.12 & 419.7 & 431.8 & 105.447 & $18,17,16\left(\mathrm{H}_{2} \mathrm{O}\right)$ \\
\hline 6 & $490-702$ & -0.51 & - & - & - & $30,28\left(\mathrm{NO}, \mathrm{CO} / \mathrm{N}_{2}\right.$, oxidation product, small $)$ \\
\hline
\end{tabular}

Table 2 Thermal decomposition characteristics of compounds $\mathbf{1 a}$ and $\mathbf{1 b}$ in synthetic air atmosphere

\begin{tabular}{|c|c|c|c|c|c|c|}
\hline Step & $\begin{array}{l}\text { Tem- } \\
\text { perature } \\
\text { range } /{ }^{\circ} \mathrm{C}\end{array}$ & $\Delta m / \%$ & $\begin{array}{l}\text { DTG peak } \\
\text { temperature } /{ }^{\circ} \mathrm{C}\end{array}$ & $\begin{array}{l}\text { DSC peak } \\
\text { temperature } /{ }^{\circ} \mathrm{C}\end{array}$ & $\Delta H / \mathrm{kJ} \mathrm{mol}^{-1}$ & Main fragments $/ \mathrm{m} / z$ values \\
\hline \multicolumn{7}{|l|}{ 1a } \\
\hline 1 & $60-159$ & 1.27 & 150.7 & 151.0 & 35.00 & $18,17\left(\mathrm{H}_{2} \mathrm{O}\right)$ \\
\hline 2 & 159-264 & 8.38 & 199.3 & 204.3 & 535.22 & $\begin{array}{l}18,17\left(\mathrm{H}_{2} \mathrm{O}\right) \\
45,44\left(\mathrm{Me}_{2} \mathrm{NH}\right) \mathrm{Me}_{2} \mathrm{NH} \\
\quad \text { degradation products }\end{array}$ \\
\hline 3 & $264-344$ & 1.73 & 332.2 & 364.2 & 3145.03 & $18,17\left(\mathrm{H}_{2} \mathrm{O}\right)$ \\
\hline 4 & $344-444$ & 3.86 & 363.5 & & & $45,44\left(\mathrm{Me}_{2} \mathrm{NH}\right)$ \\
\hline 5 & $444-535$ & 1.28 & 464.0 & 461.0 & -1732.99 & $44\left(\mathrm{CO}_{2}, \mathrm{~N}_{2} \mathrm{O}\right)$ \\
\hline 6 & $535-698$ & 0.40 & - & - & - & - \\
\hline \multicolumn{7}{|l|}{ 1b } \\
\hline 1 & $35-178$ & 5.35 & 119.9 & 124.5 & 307.79 & $18,17\left(\mathrm{H}_{2} \mathrm{O}\right)$ \\
\hline 2 & & & 152.8 & 158.8 & 47.95 & $18,17\left(\mathrm{H}_{2} \mathrm{O}\right)$ \\
\hline 3 & $178-262$ & 6.77 & 230.4 & 233.0 & 427.09 & $45,44\left(\mathrm{Me}_{2} \mathrm{NH}\right)$ \\
\hline 4 & $262-300$ & 0.53 & 281.3 & & & \\
\hline 5 & $300-347$ & 1.32 & 334.7 & 378.3 & -1317.24 & $18,17\left(\mathrm{H}_{2} \mathrm{O}\right)$ \\
\hline 6 & $347-443$ & 3.75 & 365.4 & & & $45,44,43\left(\mathrm{Me}_{2} \mathrm{NH}\right)$ \\
\hline 7 & $443-523$ & 1.66 & 484.3 & 485.5 & -2145.26 & $44\left(\mathrm{CO}_{2}, \mathrm{~N}_{2} \mathrm{O}\right)$ \\
\hline 8 & $523-698$ & 0.15 & - & - & - & $44\left(\mathrm{CO}_{2}, \mathrm{~N}_{2} \mathrm{O}\right)$ \\
\hline
\end{tabular}

Now we turn to the detailed analysis of the decomposition curves. In inert atmosphere, the decomposition of compounds 1a starts with elimination of the two most weakly bound water of crystallization molecules/mol $(\mathrm{m} / \mathrm{z}=18,17$, 16) up to $150{ }^{\circ} \mathrm{C}$ (Fig. 5). Compound $\mathbf{1 b}$, in contrast, loses $5 \mathrm{~mol} \mathrm{H}_{2} \mathrm{O} / \mathrm{mol}$ already by $120^{\circ} \mathrm{C}$ (Fig. 6). According to the
XRD patterns, the lattice of compound 1a does not collapse due to removal of the first two moles of water (ESI Fig. 6), which means that the water is eliminated from the holes of the structure. The intensity of IR bands related to the water of crystallization molecules decreased (ESI Fig. 7) upon heating. The lattice of compound $\mathbf{1 b}$ also survives the loss of 

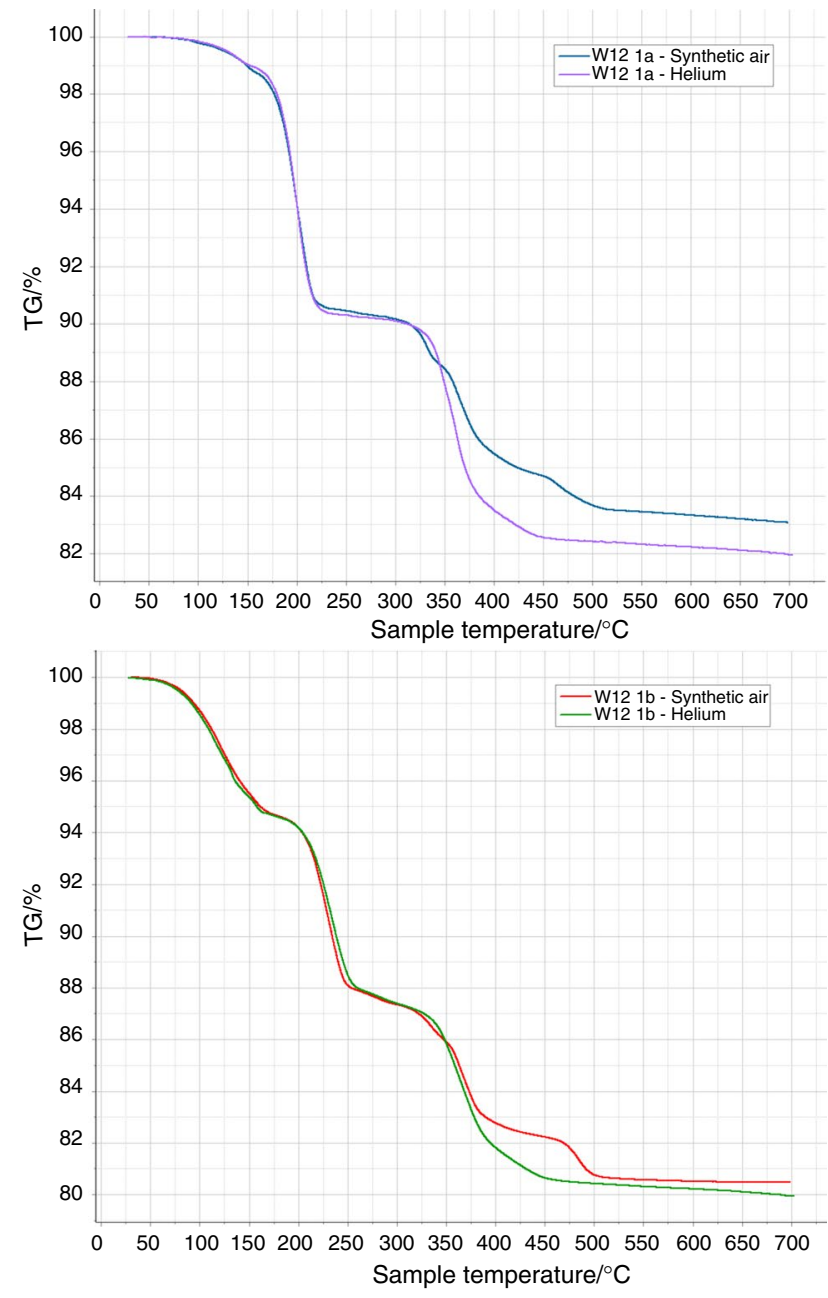

Fig. 1 The effect of atmosphere on thermal decomposition of compound $1 \mathbf{a}$ and $\mathbf{1 b}$ under helium and synthetic air

the first 5 water molecules. The reduction of the intensities of the IR peaks of water of crystallization is more expressed for $\mathbf{1 b}$ than for 1a. It is obvious that compound 1a is thermally more stable than compound $\mathbf{1 b}$ and larger amount of water is eliminated from compound $\mathbf{1 b}$ before disruption of lattice (Tables 1, 2, ESI Fig. 3 and 4).

The more strongly bound water molecules also leave the crystals in the next endothermic decomposition steps, occurring at $\sim 140 / \sim 200{ }^{\circ} \mathrm{C}$ and $\sim 120 / \sim 160{ }^{\circ} \mathrm{C}$ (both in $\mathrm{He}$ and in synthetic air) for $\mathbf{1 a}$ and $\mathbf{1 b}$, respectively. However, at these temperatures simultaneously with water, dimethylamine also evolves. The decomposition curves are almost the same in both inert and oxidizing atmospheres (Figs. 5, 6 and Tables 1,2). From this, one can conclude that the aerial oxygen is not involved in these processes directly. The loss of the amine and the additional water molecules, however, disrupts the crystal lattice, and an XRD amorphous intermediate is formed (ESI Fig. 6). On further heating, two additional endothermic processes are observed for both
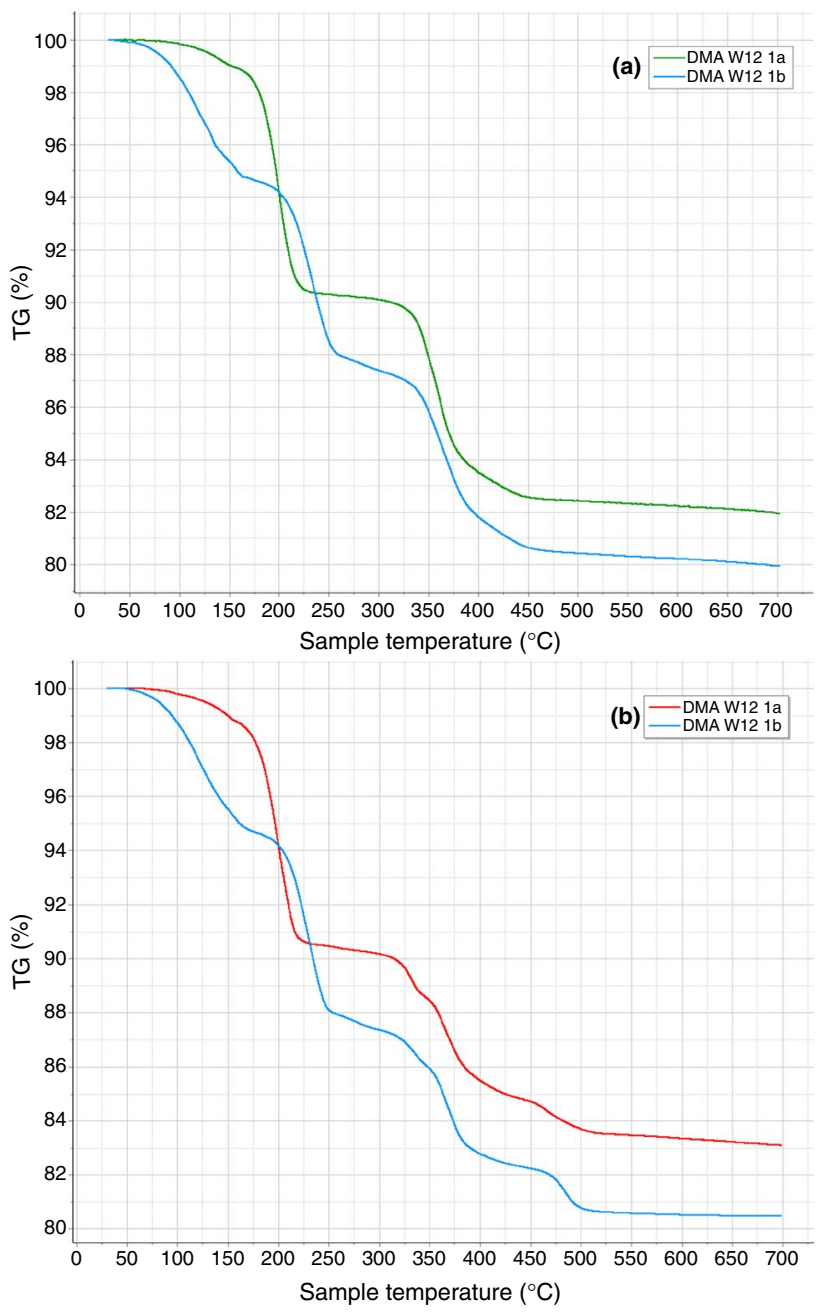

Fig. 2 Comparison of thermal decomposition characteristics of compound 1a and 1b under helium (a) and synthetic air (b) atmospheres

compounds at around 348 and $365^{\circ} \mathrm{C}$ in inert atmosphere (ESI Figs. 8-12). Besides the appearance of dimethylamine, its degradation and oxidative coupling products $(\mathrm{m} / \mathrm{z}=58$ and 59), and as a consequence of the oxidation, formation of water can also be observed (Figs. 7, 8) and ESI Fig. 13-16). In synthetic air, strongly exothermic processes take place at similar temperatures, indicating the oxidation of dimethylamine by the aerial oxygen. The analysis of the gas evolved from compound 1a in inert atmosphere showed that in inert atmosphere, no redox reaction takes place at $203{ }^{\circ} \mathrm{C}$ (Fig. 7) and only water (of crystallization) and dimethylamine peaks appear. Above $300{ }^{\circ} \mathrm{C}$ (Fig. 8), the intensities of dimethylamine peaks compared with those of water decrease with simultaneous appearance of oxidative condensation products of dimethylamine $(\mathrm{m} / \mathrm{z}=58$ and 59). Since the water of crystallization is eliminated from polyoxometalates at temperatures below $250{ }^{\circ} \mathrm{C}$, and the dehydroxylation temperatures [ [10], [14], [18] ] of the polytungstate cages are 
Fig. 3 DSC curves of compound 1a in inert (purple) and synthetic air (blue) atmosphere. (Color figure online)

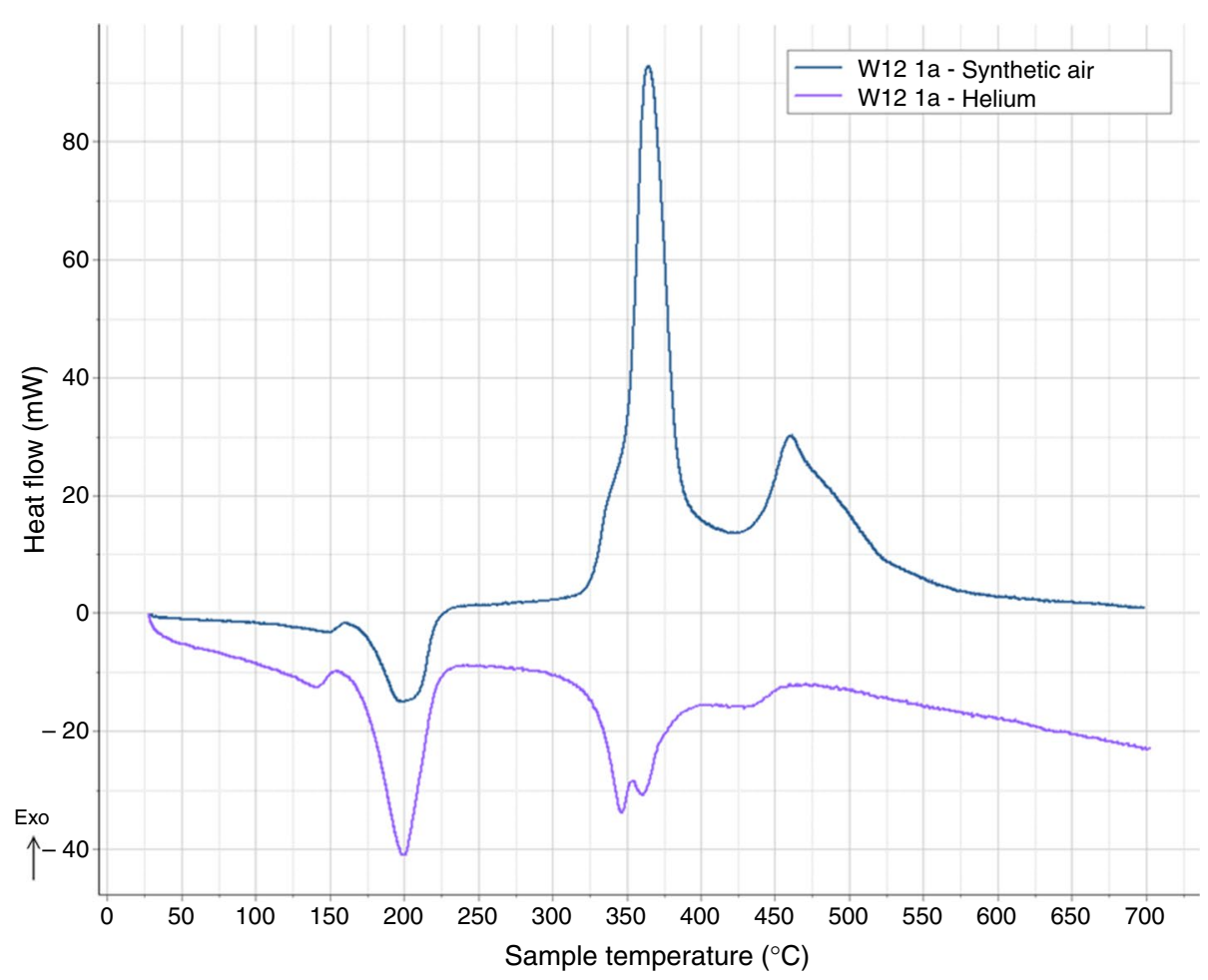

Fig. 4 DSC curves of compound $\mathbf{1 b}$ in inert (green) and synthetic air (red) atmosphere. (Color figure online)

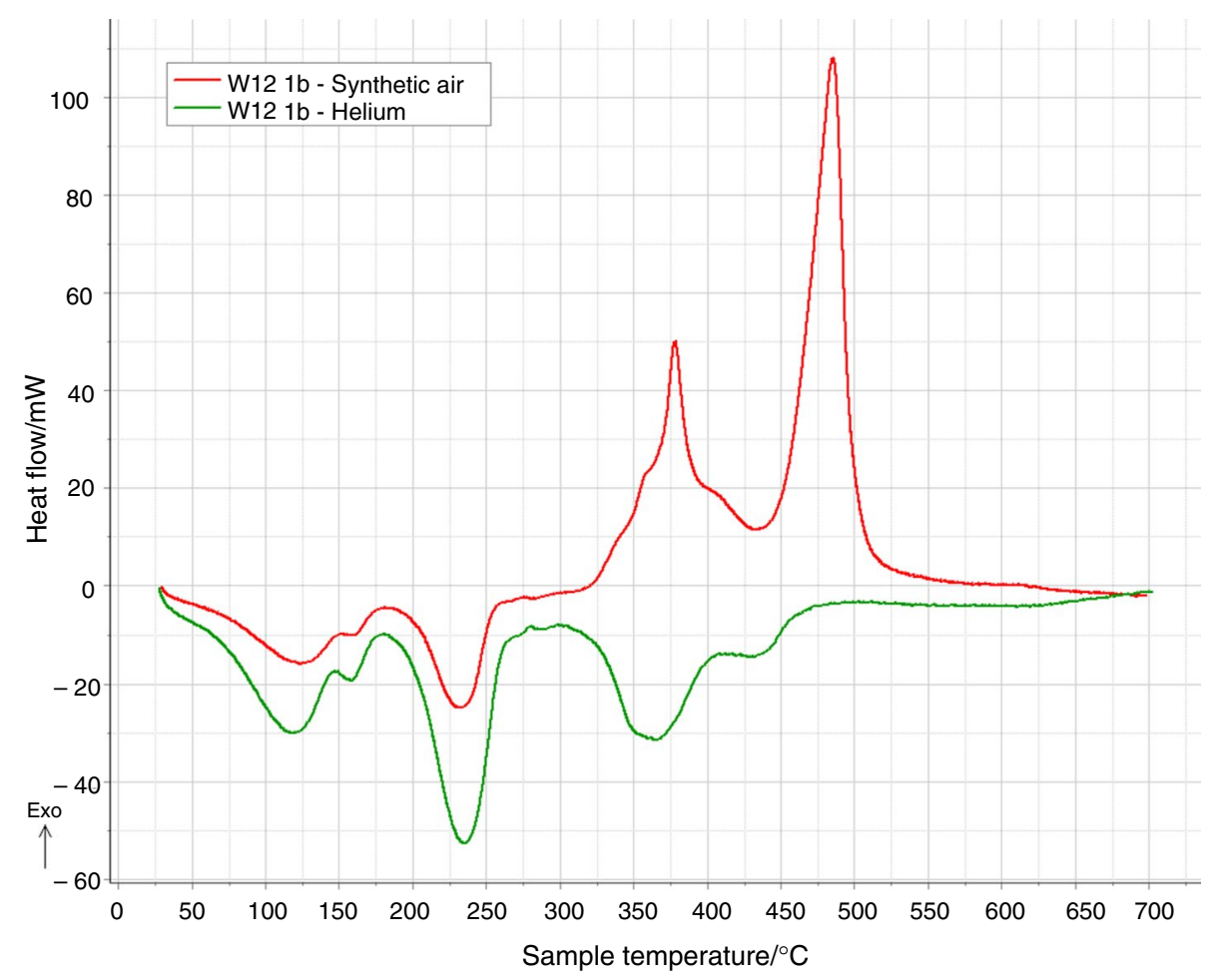

above $400{ }^{\circ} \mathrm{C}$, the source of water at around $300{ }^{\circ} \mathrm{C}$ can only be the polytungstate cage via the expected redox reaction between the amine/ammonium and $\mathrm{W}=\mathrm{O}$ functionalities. Further evidence of the redox reaction is that according to the XRD pattern, the residue formed by heating up to $700^{\circ} \mathrm{C}$ in inert atmosphere is reduced tungsten oxides like $\mathrm{WO}_{\sim 2.93}$. The color of the final decomposition product (which is the same for both $\mathbf{1 a}$ and $\mathbf{1 b}$ ) is green, confirming the presence of blue reduced $\mathrm{Mo}^{5+}$ centers in the yellow $\mathrm{WO}_{3}$ matrix. The amount of the products of the oxidation of dimethylamine, 


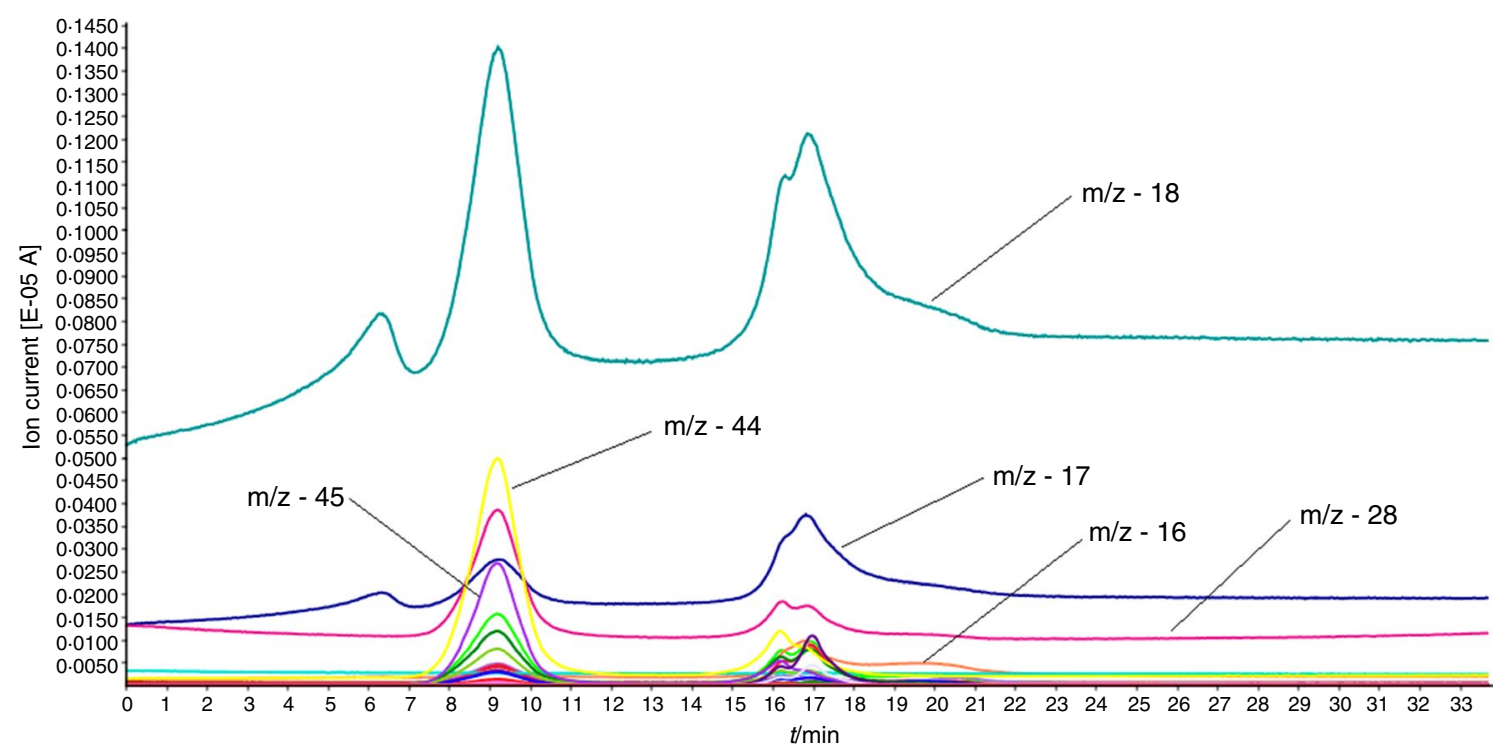

Fig. 5 Ion chromatograms for $\mathrm{H}_{2} \mathrm{O}(\mathrm{m} / \mathrm{z}=18,17,16)$ and dimethylamine $(\mathrm{m} / \mathrm{z}=45,44,28,16)$ fragments on heating of compounds 1a in inert atmosphere

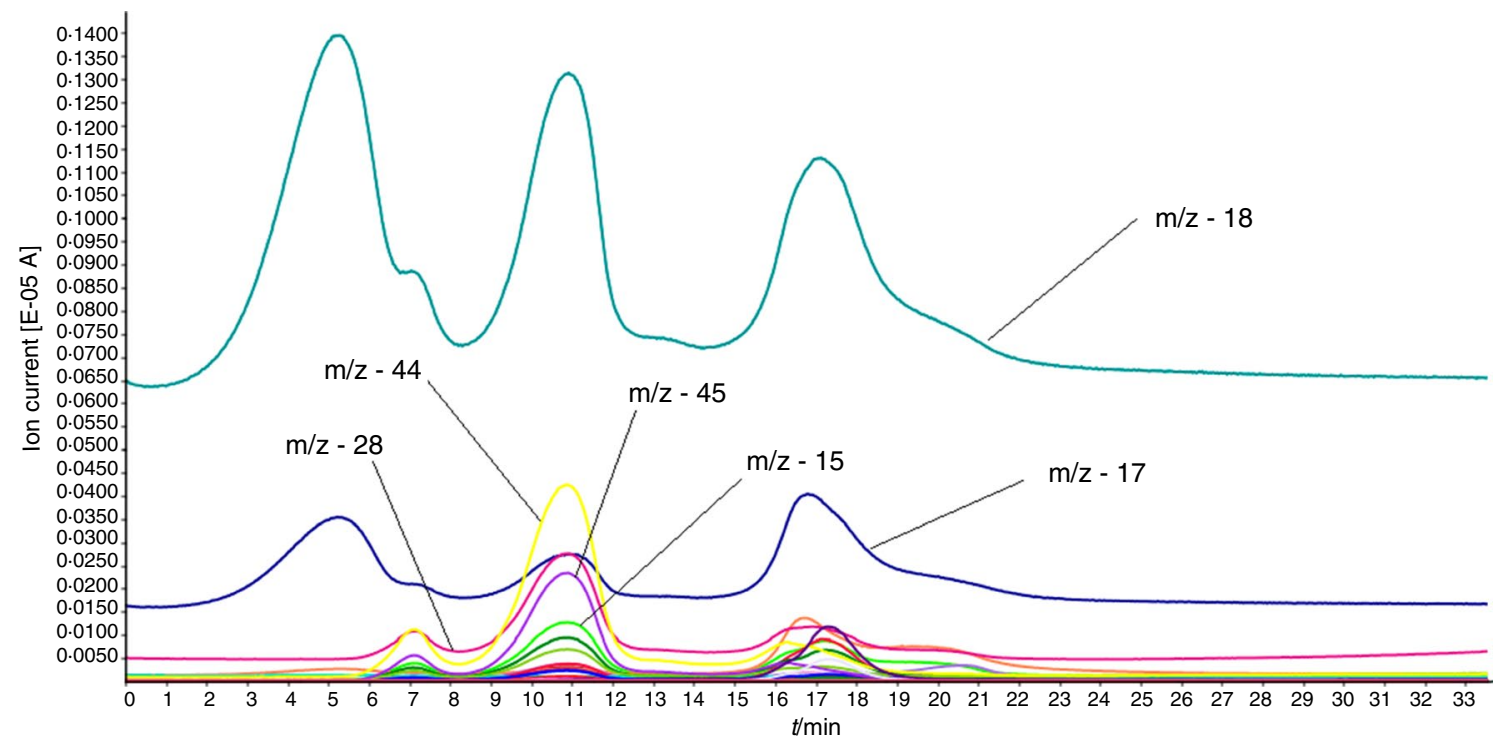

Fig. 6 Ion chromatograms for $\mathrm{H}_{2} \mathrm{O}(\mathrm{m} / \mathrm{z}=18,17)$ and dimethylamine $(\mathrm{m} / \mathrm{z}=45,44,28,15)$ fragments on heating of compounds $\mathbf{1 b}$ in inert atmosphere

namely $\mathrm{CO}_{2}(m / z=44), \mathrm{CO}(m / z=28), \mathrm{NO}(m / z=30), \mathrm{N}_{2} \mathrm{O}$ $(m / z=44)$ or $\mathrm{NO}_{2}(m / z=46)$, cannot be determined precisely because their characteristic peaks coincide with those of the main fragments of $\mathrm{Me}_{2} \mathrm{NH}\left(\right.$ e.g., $m / z=44\left(\mathrm{Me}_{2} \mathrm{~N}\right)$ and 28 $\left(\mathrm{CH}_{2} \mathrm{~N}\right)$ (ESI Fig. 17). Note, however, that the intensities of the peaks at $m / z=44,28$ and 30 relative to each other and to the $\mathrm{Me}_{2} \mathrm{NH}$ peak at $m / z=45$ differ from those observed for dimethylamine (ESI Fig. 17).
Since the majority of the $\mathrm{Me}_{2} \mathrm{NH}$ evolves at lower temperatures, it is reasonable to assume that the dimethylammonium ions that react above $300{ }^{\circ} \mathrm{C}$ with the polytungstate cage are the most strongly bound ones, and the strong interaction between the $\mathrm{N}-\mathrm{H}$ and $\mathrm{O}=\mathrm{W}$ functionalities might initiate a solid-phase quasi-intramolecular redox reaction between the organic cation and the oxometallate anion. It cannot be excluded, however, that the gaseous $\mathrm{Me}_{2} \mathrm{NH}$ liberated is oxidized by the solid-state polytungstate cages. The 


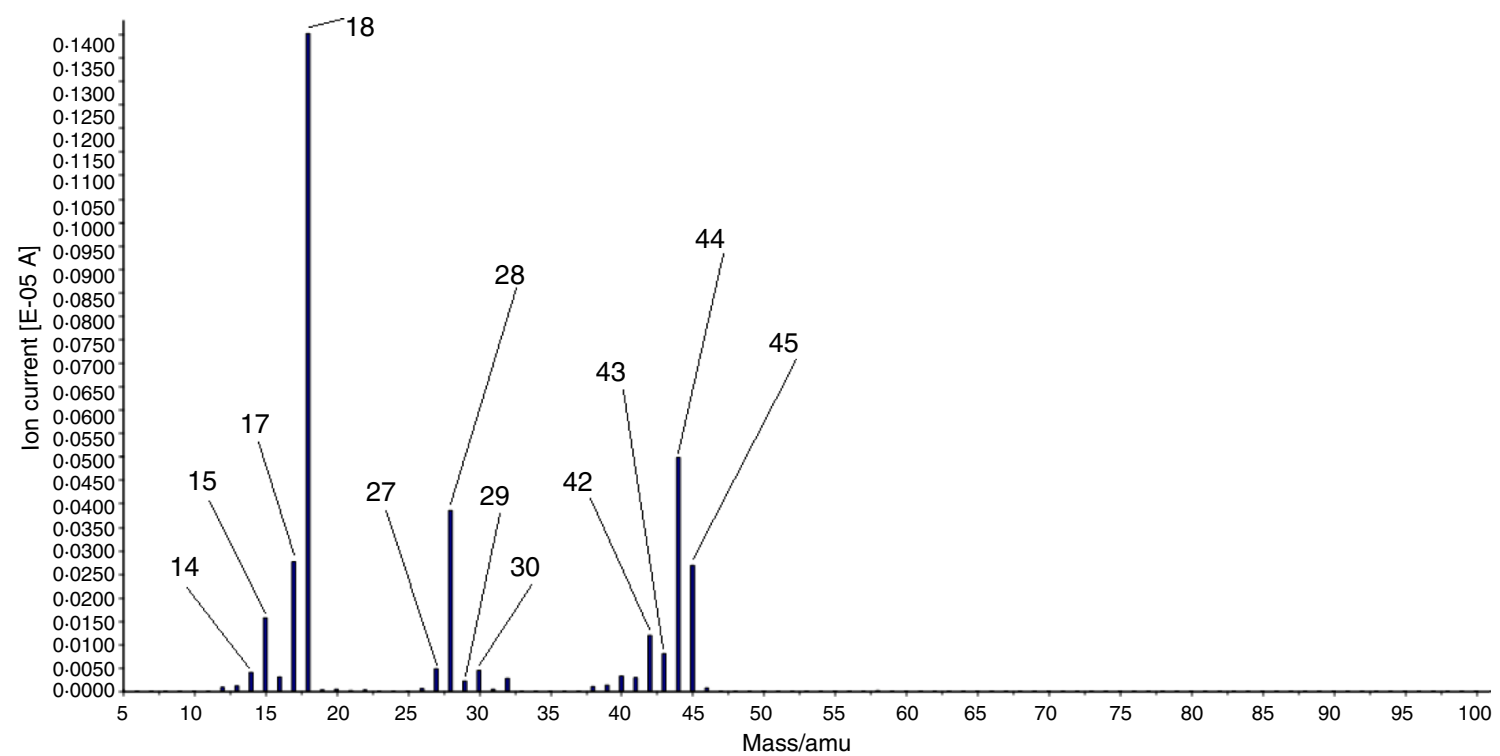

Fig. 7 Evolved gas mass spectra of gaseous compounds formed from compound $\mathbf{1 a}$ on heating at $203{ }^{\circ} \mathrm{C}$ under inert atmosphere

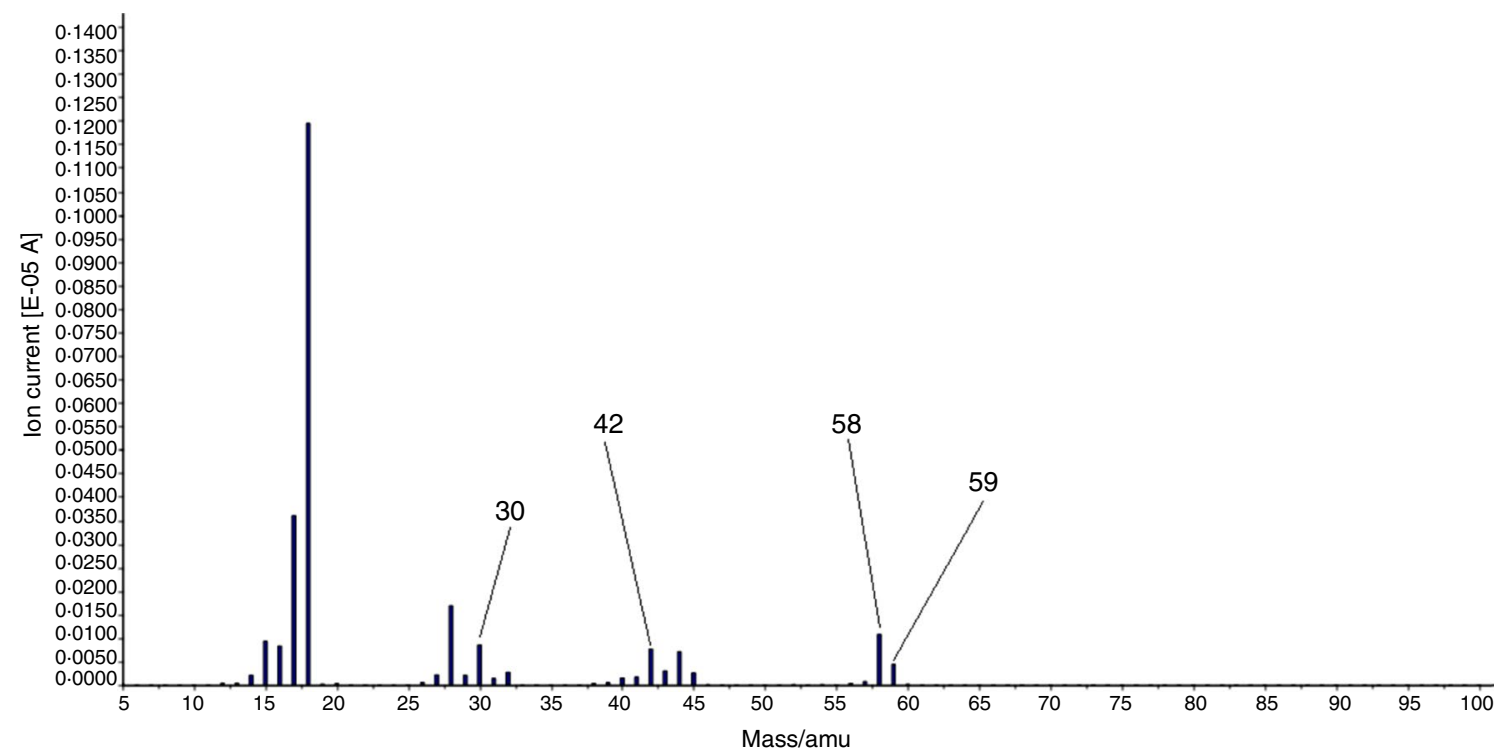

Fig. 8 Evolved gas mass spectra of gaseous compounds formed from compound 1a on heating at $365^{\circ} \mathrm{C}$ under inert atmosphere

number and binding energy of dimethylammonium ions are different in the structures of compounds $\mathbf{1 a}$ and $\mathbf{1 b}$ [8], and thus it is not surprising that some differences can be seen in the mass losses and the temperatures of lattice disruption and the collapse of the polytungstate cages.

In the final phase of decomposition of compound 1a that takes place in inert atmosphere at $441^{\circ} \mathrm{C}$, i.e., after the complete removal of organic components, evolution of some gaseous product is observed, which was found to contain only water (Fig. 9). The only source of water in this case can only be the polytungstate cage, namely its inner hydroxyl groups.
From this, one can conclude that the polytungstate cage collapse completely at around $450{ }^{\circ} \mathrm{C}$.

The total mass losses of the samples in inert atmosphere were found to be a bit higher than the theoretical value calculated for formation of $\mathrm{WO}_{3}$ from $\left(\mathrm{Me}_{2} \mathrm{NH}_{2}\right)_{10} \mathrm{H}_{2} \mathrm{~W}_{12} \mathrm{O}_{42} \cdot \mathrm{nH}_{2} \mathrm{O}$ ( $n=10$ or 11$)$. The reason for this, as mentioned above, is that the final decomposition product in the absence of external oxygen is $\mathrm{WO}_{\sim 2.93}$ reduced tungsten oxide.

The TG-MS decomposition curves observed in synthetic air for both $\mathbf{1 a}$ and $\mathbf{1 b}$ at low temperatures show the 


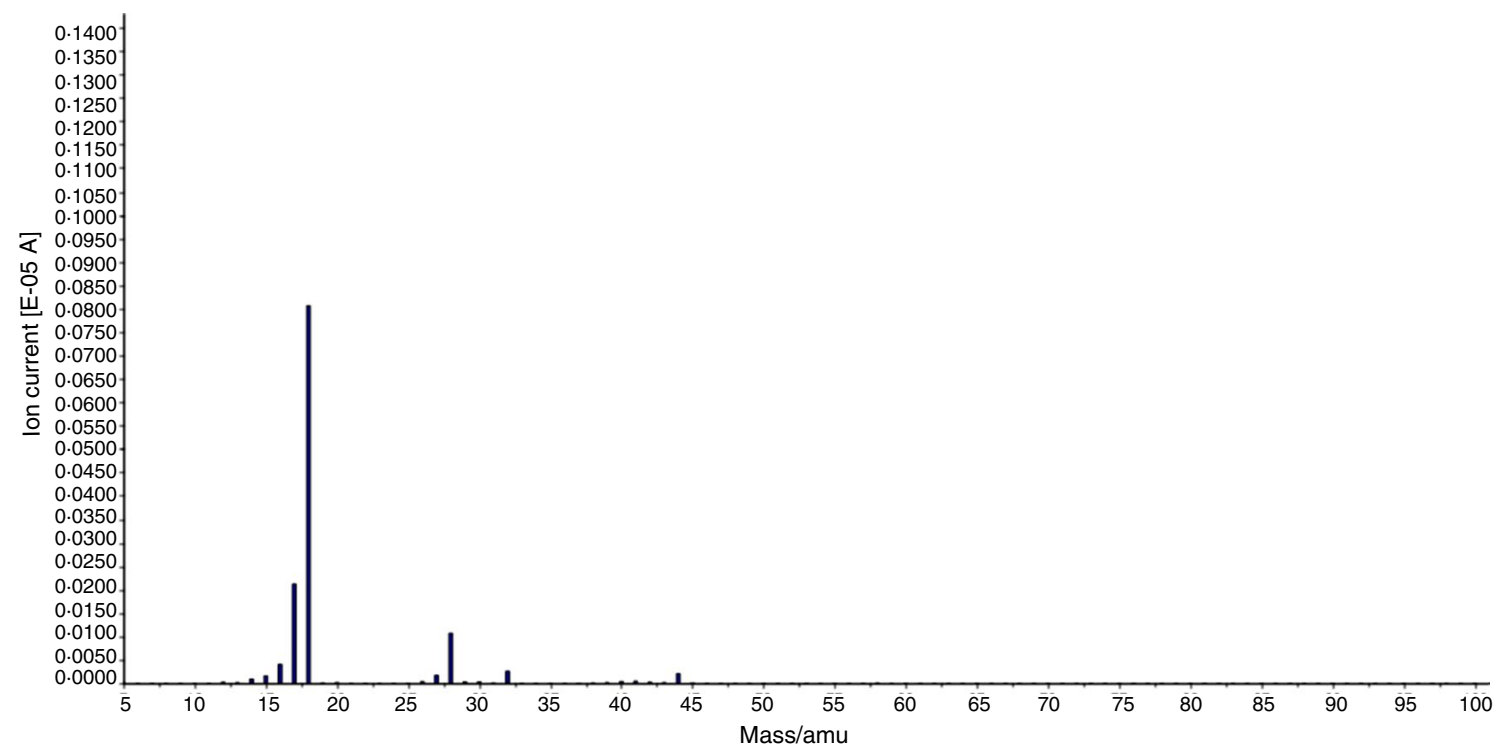

Fig. 9 Evolved gas mass spectra of gaseous compounds formed from compound 1a on heating at $441{ }^{\circ} \mathrm{C}$ under inert atmosphere

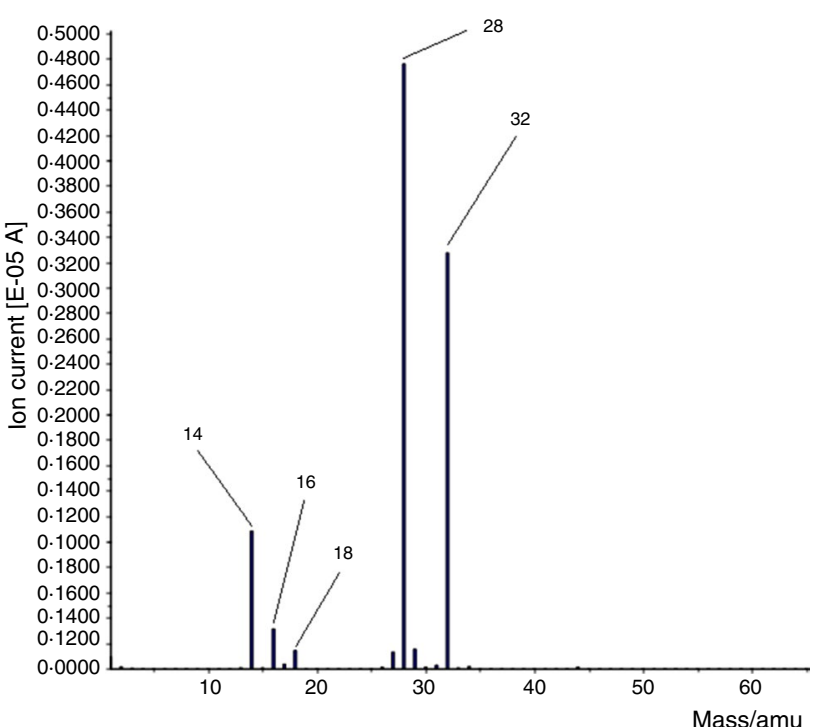

Fig. 10 TG-MS of gases evolved from compound $1 \mathbf{a}$ at $109{ }^{\circ} \mathrm{C}$ in synthetic air

same steps as in inert atmosphere, namely evolution of pure water in the first step, followed by simultaneous evolution of water and dimethylamine. At higher temperatures, the gaseous products correspond to the oxidation of dimethylamine (Figs. 10-12) until it is completely consumed. The final product in this case proved to be pure monoclinic $\mathrm{WO}_{3}$ (ESI Figs. 6 and 7).

The MS-EGA spectrum obtained at $109^{\circ} \mathrm{C}$ (Fig. 10) shows that the components of synthetic air, $\mathrm{N}_{2}(\mathrm{~m} / \mathrm{z}=28$ $\left(\mathrm{N}_{2}\right)$ and $14\left(\mathrm{~N}^{+}\right), \mathrm{O}_{2}\left(\mathrm{~m} / \mathrm{z}=32\left(\mathrm{O}_{2}^{+}\right)\right.$and $16\left(\mathrm{O}^{+}\right)$and water $\left(m / z=18\left(\mathrm{H}_{2} \mathrm{O}^{+}\right), 17\left(\mathrm{OH}^{+}\right), 16\left(\mathrm{O}^{+}\right)\right)$could be detected. The

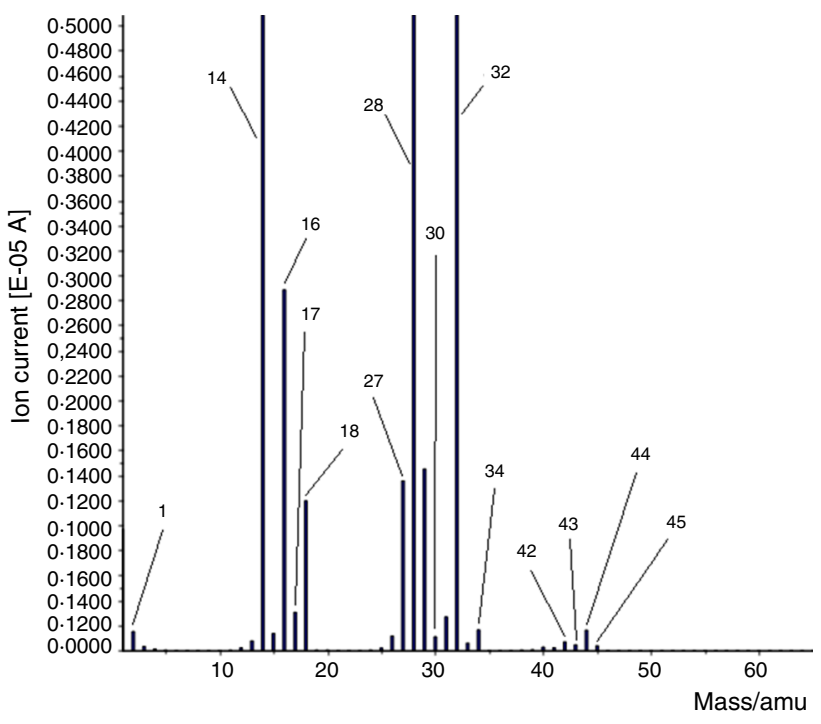

Fig. 11 TG-MS of gases evolved from compound 1a at $214{ }^{\circ} \mathrm{C}$ in synthetic air

intensity of the $m / z=16$ peak is higher than the intensity of $m / z=18$ and 17 peaks, although the fragmentation pattern of $\mathrm{OH}_{2}{ }^{+}$shows that the peak intensities of the fragment ions decreases in the $\mathrm{OH}_{2}^{+}-\mathrm{OH}^{+}-\mathrm{O}^{+}$order [19]. The relatively more $\mathrm{O}^{+}$formation can obviously be attributed due to the fragmentation of the mother ion of aerial oxygen, $\mathrm{O}_{2}^{+}$to yield $\mathrm{O}^{+}$also.

At $214{ }^{\circ} \mathrm{C}$ (Fig. 11) the disruption of lattice (ESI Fig. 6) and formation of dimethylamine $(\mathrm{m} / \mathrm{z}=45)$, its protonated form $(\mathrm{m} / z=46)$ and fragments could be observed, together with water evolution. No sign of high amount of 


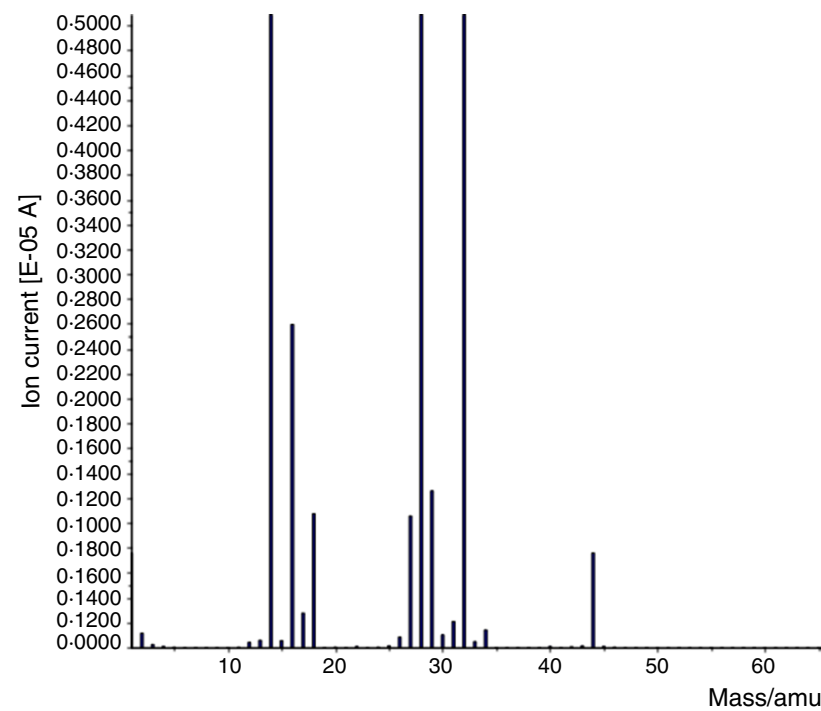

Fig. 12 TG-MS of gases evolved from compound $1 \mathrm{a}$ at $523{ }^{\circ} \mathrm{C}$ in synthetic air

$\mathrm{CO}_{2}(m / z=44)$ evolution, the peaks of $m / z=28$ may not be evaluated as $\mathrm{CO}+$ fragment due to the presence of aerial $\mathrm{N}_{2}(m / z=28)$.

At even higher temperature, $523{ }^{\circ} \mathrm{C}$ (Fig. 12), after the degradation products of organic part $(\mathrm{m} / \mathrm{z}=27,29,32$, 14), water $(\mathrm{m} / \mathrm{z}=18,17)$ and $\mathrm{CO}_{2} / \mathrm{N}_{2} \mathrm{O}(\mathrm{m} / \mathrm{z}=44)$ could be detected. There are no dimethylamine peaks at this temperature, only the fragment ions from the nonvolatile organic products. The compound $\mathbf{1 b}$ shows similar behavior in synthetic air (ESI Fig. 18a-e). Only air and water could be detected at $131{ }^{\circ} \mathrm{C}$ without any organic fragment. A small amount of dimethylamine was formed between 166 and $236{ }^{\circ} \mathrm{C}$, while the amount of amine evolved together with the degradation products was increased at $373{ }^{\circ} \mathrm{C}$. At $471{ }^{\circ} \mathrm{C}$, mainly degradation products formed with $\mathrm{CO}_{2}$ as oxidation product without free amine formation. The volatile oxidative coupling products could not be detected at all (ESI Fig. 18a-e), which shows that the aerial oxygen oxidizes them.

When the heating rate is increased, the peak temperatures of thermal decomposition steps are shifted. In the case of compound 1a (ESI Fig. 19-21), the rate of mass loss drastically decreases with increasing the heating rate from 10 to $20^{\circ} \mathrm{C} \mathrm{min}{ }^{-1}$. There is no similar change in the case of compound $\mathbf{1 b}$. In the DTG curves (ESI Fig. 20) can be seen that not only the peak temperatures are shifted, but the intensity of each peak is also changed. At $20{ }^{\circ} \mathrm{C}$ $\mathrm{min}^{-1}$ heating rate, in the case of compound $1 \mathbf{a}$, new peaks appeared at $100{ }^{\circ} \mathrm{C}$ and $310^{\circ} \mathrm{C}$.

The DSC curves showed exothermicity for both compounds in the oxidation range $\left(>300{ }^{\circ} \mathrm{C}\right)$ due to uncontrolled burning processes, but in the low temperature range, only the DSC curves for compound 1a changed with varying the heating rate from 10 to $20^{\circ} \mathrm{C} \mathrm{min}{ }^{-1}$. According to the appearance of the new peak in the DTG curve around $100{ }^{\circ} \mathrm{C}$, an endothermic peak appears in the DSC as well as the consequence of water elimination (ESI Fig. 19).

Comparing the type and relative amount oxidation and degradation products in inert atmosphere and aerial conditions for compounds $\mathbf{1 a}$ and $\mathbf{1 b}$, it can be concluded that in air, the burning of liberated dimethylamine takes place. The lack of reduced tungsten oxides might be attributed to re-oxidation of the reduced tungsten oxides formed by air at this temperature [20].

\section{Conclusions}

The general characteristics of thermal decomposition are similar for the two solvatomorphs of decakis(dimethylammonium) dihydrogendodecatungstate $\left(\left(\mathrm{Me}_{2} \mathrm{NH}_{2}\right)_{10} \mathrm{H}_{2} \mathrm{~W}_{12} \mathrm{O}_{42} \cdot 10 \mathrm{H}_{2} \mathrm{O}\right.$ and $\left.11 \mathrm{H}_{2} \mathrm{O}\right)$, but some differences could be observed in the amount of water eliminated in the first decomposition steps and in the resolution/ shifting of the decomposition peak temperatures depending on the heating rate or atmosphere used.

The first step of decomposition is endothermic in both atmosphere and involving 2 and 5 water molecule elimination with $\sim 150$ and $\sim 120{ }^{\circ} \mathrm{C}$ peak temperatures for the decahydrate and undecahydrate, respectively. The elimination of further water and dimethylamine was observed with increasing the temperature, and the lattice of compounds started to disrupt above $200{ }^{\circ} \mathrm{C}$. Until $300{ }^{\circ} \mathrm{C}$, these processes are endothermic in both atmosphere, the further decomposition processes at higher temperature are left to be endothermic in helium, but become exothermic in synthetic air atmosphere.

In helium atmosphere, above $350{ }^{\circ} \mathrm{C}$, a solid-phase quasiintramolecular redox reaction takes place when the dimethylamine degradation products react with the $\mathrm{W}=\mathrm{O}$ bonds with formation of oxidative coupling products of the organic fragments and reduced tungsten oxide with $\mathrm{WO}_{\sim 2.93}$ composition. In synthetic air, above $350{ }^{\circ} \mathrm{C}$, a burning process of organic fragments takes place, there are no oxidative coupling products and reduced tungsten oxide formation due to oxidation of these by the aerial oxygen. The end products of decomposition are $\mathrm{CO}_{2}, \mathrm{H}_{2} \mathrm{O}$ and monoclinic $\mathrm{WO}_{3}$.

Electronic supplementary material The online version of this article (https://doi.org/10.1007/s10973-020-10494-4) contains supplementary material, which is available to authorized users.

Acknowledgements The research within Project No. VEKOP-2.3.216-2017-00013 was supported by the European Union and the State of Hungary, co-financed by the European Regional Development Fund. N. V. M. and P. B. are grateful to the Hungarian Scientific Research 
Fund (K-124544 and K-115762). An NRDI K 124212 and an NRDI TNN_16 123631 Grants are acknowledged. The research reported in this paper was supported by the Higher Education Excellence Program of the Ministry of Human Capacities in the frame of Nanotechnology and Materials Science research area of Budapest University of Technology (BME FIKP-NAT).

Funding Open Access funding provided by Budapest University of Technology and Economics.

Open Access This article is licensed under a Creative Commons Attribution 4.0 International License, which permits use, sharing, adaptation, distribution and reproduction in any medium or format, as long as you give appropriate credit to the original author(s) and the source, provide a link to the Creative Commons licence, and indicate if changes were made. The images or other third party material in this article are included in the article's Creative Commons licence, unless indicated otherwise in a credit line to the material. If material is not included in the article's Creative Commons licence and your intended use is not permitted by statutory regulation or exceeds the permitted use, you will need to obtain permission directly from the copyright holder. To view a copy of this licence, visit http://creativecommons.org/licenses/by/4.0/.

\section{References}

1. Szilágyi IM, Sajó I, Király P, Tárkányi G, Tóth AL, Szabó A, et al. Phase transformations of ammonium tungsten bronzes. J Therm Anal Calorim. 2009;98:707-16.

2. Hunyadi D, Sajó I, Szilágyi IM. Structure and thermal decomposition of ammonium metatungstate. J Therm Anal Calorim. 2014;116(1):329-37.

3. Madarász J, Szilágyi IM, Hange F. Pokol Gy, Comparative evolved gas analyses (TG-FTIR, TG/DTA-MS) and solid state (FTIR, XRD) studies on thermal decomposition of ammonium paratungstate tetrahydrate (APT) in air. J Anal Appl Pyrol. 2004;72:197-201.

4. Gumerova NI, Rompel A. Synthesis, structures and applications of electron-rich polyoxometalates. Nat Rev Chem. 2018. https:// doi.org/10.1038/s41570-018-0112.

5. Ichihara J, Sasaki Y. Participation of new active species in epoxidation with cetylpyridinium dodecatungstate/FAp/urea- $\mathrm{H}_{2} \mathrm{O}_{2}$ system. Catal Today. 2006;117(1-3):120-5.

6. Xiao Z, Tan Y, Ma J, Wang D, Yu L, Yue F, et al. Fast swelling behaviors of thermosensitive poly ( $N$-isopropylacrylamide-co - methacryloxyethyltrimethyl ammonium chloride)/ Na2 WO4 cationic composite hydrogels. J Appl Pol Sci. 2018;135(25):46375-46375.

7. Salkar AV, Naik AP, Joshi VS, Haram SK, Morajkar PP. Designing a 3D nanoporous network via self-assembly of WO3 nanorods for improved electrocapacitive performance. Cryst Eng Commun. 2018;20(42):6683-94.

8. Lendvay G, Majzik E, Bereczki L, Domján A, Trif L, Sajó IE, et al. Dodecatungstate cages embedded in a variable dimethylammonium cation + water of crystallization matrix in the new $\left(\mathrm{Me}_{2} \mathrm{NH}_{2}\right)_{10}$. RSC Adv. 2020 (submitted).
9. Majzik E, Franguelli FP, Lendvay G, Trif L, Németh C, Farkas A, et al. Vibrational spectroscopy of dimethylammonium paratungstate-B hydrates. Z Anorg Allg Chemie. 2020. https://doi. org/10.1002/zaac.202000283.

10. Fait MJG, Lunk HJ, Feist M, Schneider M, Dann JN, Frisk TA. Thermal decomposition of ammonium paratungstate tetrahydrate under non- reducing conditions: characterization by thermal analysis, X-ray diffraction and spectroscopic methods. Thermochim Acta. 2008;469(1-2):12-22.

11. Sajó IE, Bakos LP, Szilágyi IM, Lendvay G, Magyari J, Mohai $\mathrm{M}$, et al. Unexpected sequential $\mathrm{NH}_{3} / \mathrm{H}_{2} \mathrm{O}$ solid/gas phase ligand exchange and quasi-intramolecular self-protonation yield. Inorg Chem. 2018;57(21):13679-92.

12. Sajó IE, Kovács GB, Pasinszki T, Bombicz PA, May Z, Szilágyi IM, et al. The chemical identity of " $\left[\mathrm{Ag}(\mathrm{py})_{2}\right] \mathrm{MnO}_{4}$ " organic solvent soluble oxidizing agent and new synthetic routes for the preparation of $[\mathrm{Ag}(\mathrm{py}) \mathrm{n}] \mathrm{XO} 4(\mathrm{X}=\mathrm{Mn}, \mathrm{Cl}$, and $\mathrm{Re}, \mathrm{n}=2-4) \mathrm{com}-$ plexes. J Coord Chem. 2018;71(16-18):2884-904.

13. Kovács GB, May NV, Bombicz PA, Klébert S, Németh P, Menyhárd $\mathrm{A}$, et al. An unknown component of a selective and mild oxidant: structure and oxidative ability of a double salt-type complex having $\kappa 1 \mathrm{O}$-coordinated permanganate anions and three- and fourfold coordinated silver cations. R Soc Chem. 2019;9:28387-98.

14. Arnaiz A, Cuadrado L, Santiago C, Lorente L, Arrieta JM. Synthesis, characterization and thermogravimetric decomposition of 2-ethylpyridinium metatungstate monohydrate. Kinetic study of its thermal dehydration. J Therm Anal Calorim. 1987;32(5):1449-56.

15. Holló BB, Petruševski VM, Kovács GB, Franguelli FP, Farkas A, Menyhárd A, et al. Thermal and spectroscopic studies on a double-salt-type pyridine-silver perchlorate complex having $\kappa 1-\mathrm{O}$ coordinated perchlorate ions. J Therm Anal Calorim. 2019;138(2):1193-205.

16. Kótai L, Sajó IE, Jakab E, Keresztury G, Németh C, Gács I, et al. Studies on the chemistry of $[\mathrm{Cd}(\mathrm{NH} 3) 4]\left(\mathrm{MnO}_{4}\right)^{2}$. A low temperature synthesis route of the $\mathrm{CdMn}_{2} \mathrm{O}_{4}+\mathrm{x}$ type $\mathrm{NOx}$ and $\mathrm{CH} 3 \mathrm{SH}$ sensor precursors. Z Anorg Allgem Chem. 2012;638(1):177-86.

17. Kótai L, Gács I, Sajó IE, Sharma PK, Banerji KK. Beliefs and facts in permanganate chemistry-an overview on the synthesis and reactivity of simple and complex permanganates. Trends Inorg Chem. 2009;11:25-104.

18. Liu SJ, Chen QY, Zhang PM, Li MN. Study on thermal decom-

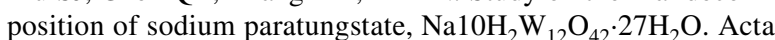
Phys Chim Sin. 1998;14:821-5.

19. Kocsis T, Magyari J, Sajó IE, Pasinszki T, Homonnay Z, Szilágyi IM, et al. Evidence of quasi-intramolecular redox reactions during thermal decomposition of ammonium hydroxodisulfitoferriate(III), $\left(\mathrm{NH}_{4}\right)_{2}\left[\mathrm{Fe}(\mathrm{OH})\left(\mathrm{SO}_{3}\right)_{2}\right] \mathrm{H}_{2} \mathrm{O}$. J Therm Anal Calorim. 2018;132(1):493-502.

20. Lassner E. Wolf-Dieter-Schubert. Tungsten blue oxide. The chemistry of non-sag tungsten. Amsterdam: Elsevier; 2013. p. 111-7.

Publisher's Note Springer Nature remains neutral with regard to jurisdictional claims in published maps and institutional affiliations. 